WSRC-TR-99-00155

KEYWORDS: Saltstone, Tetraphenylborate

RETENTION: Permanent

\title{
Benzene Evolution Rates from Saltstone Prepared with 2X ITP Flowsheet Concentrations of Phenylborates and Heated to $85^{\circ} \mathrm{C}(\mathrm{U})$
}

M. R. Poirier

May 21, 1999 
This document was prepared in conjunction with work accomplished under Contract No.

DE-AC09-96SR18500 with the U.S. Department of Energy.

\section{DISCLAIMER}

This report was prepared as an account of work sponsored by an agency of the United States Government. Neither the United States Government nor any agency thereof, nor any of their employees, makes any warranty, express or implied, or assumes any legal liability or responsibility for the accuracy, completeness, or usefulness of any information, apparatus, product or process disclosed, or represents that its use would not infringe privately owned rights. Reference herein to any specific commercial product, process or service by trade name, trademark, manufacturer, or otherwise does not necessarily constitute or imply its endorsement, recommendation, or favoring by the United States Government or any agency

thereof. The views and opinions of authors expressed herein do not necessarily state or reflect those of the United States Government or any agency thereof.

This report has been reproduced directly from the best available copy.

Available for sale to the public, in paper, from: U.S. Department of Commerce, National Technical Information Service, 5285 Port Royal Road, Springfield, VA 22161, phone: (800)

553-6847, fax: (703) 605-6900, email: orders@ntis.fedworld.gov online ordering: http://www.ntis.gov/ordering.htm

Available electronically at http://www.doe.gov/bridge

Available for a processing fee to U.S. Department of Energy and its contractors, in paper, from: U.S. Department of Energy, Office of Scientific and Technical Information, P.O. Box 62, Oak Ridge, TN 37831-0062, phone: (865 ) 576-8401, fax: (865) 576-5728, email: reports@ adonis.osti.gov 


\section{Summary}

High Level Waste Engineering (HLWE) requested SRTC to determine the effect of tetraphenylborate (TPB) and its decomposition products (i.e., triphenylboron, diphenylborinic acid, and phenylboronic acid) on the saltstone process. As part of the task, HLWE requested SRTC to measure benzene evolution rates from saltstone prepared with $2 \mathrm{X}$ In-Tank Precipitation (ITP) process flowsheet concentrations of phenylborates and heated to $85^{\circ} \mathrm{C}$ for two days to determine the effect of curing temperature on benzene release.

SRTC prepared saltstone samples containing 2X ITP flowsheet levels of TPB, triphenylboron (3PB), diphenylborinic acid (2PB), and phenylboronic acid (1PB). The samples were placed in glass kettles which were sealed. One end of kettle was connected to an air purge. An orbo tube was placed on the other end which discharged into a hood. The orbo tubes were changed periodically and analyzed to determine the amount of benzene released from the saltstone samples. One sample cured at ambient temperature. The other sample was heated to $85^{\circ} \mathrm{C}$ for two days and allowed to cool.

The results and conclusions of this test are:

- The saltstone sample which was heated to $85^{\circ} \mathrm{C}$ for two days released benzene at an average rate of $16 \mathrm{ug} / \mathrm{L} \mathrm{hr}$ over 138 days. The maximum release rate $(60 \mathrm{ug} / \mathrm{L} \mathrm{hr})$ occurred during the first seven days. The total benzene release was $27 \%$ of the theoretical maximum.

- The saltstone sample which cured at ambient temperature released benzene at an average rate of $10 \mathrm{ug} / \mathrm{L} \mathrm{hr}$ over 138 days. The maximum release rate $(17 \mathrm{ug} / \mathrm{L} \mathrm{hr})$ occurred after 70 days which is consistent with previous SRTC testing. The total benzene release was $18 \%$ of the theoretical maximum.

- The test shows the total amount of benzene released from saltstone samples during curing does not change much if the sample temperature increases to $85^{\circ} \mathrm{C}$ for a few days, but the increased temperature will cause the benzene to be released sooner and the peak release rate to be higher.

No further saltstone testing is recommended.

\section{Introduction}

The Saltstone Facility provides the final treatment and disposal of low level liquid waste streams. At the Saltstone Facility, the waste is mixed with cement, flyash, and slag to form a grout, which is pumped into large concrete vaults where it cures. The facility started radioactive operations in June 1990.

High Level Waste Engineering requested SRTC to determine the effect of TPB and its decomposition products (i.e., 3PB, 2PB, and 1PB) on the saltstone process. ${ }^{1}$ Previous testing performed by SRTC determined saltstone benzene evolution rates as a function of ITP filtrate composition. ${ }^{2}$ Testing by the Thermal Fluids Laboratory has shown at design operation, the temperature in the Z-area vaults could reach $85^{\circ} \mathrm{C}$. Saltstone asked SRTC to perform additional testing to determine whether curing at $85^{\circ} \mathrm{C}$ could change saltstone benzene evolution rates. This document describes the test performed to determine the effect of curing temperature on the benzene evolution rates.

\section{Tests}

SRTC prepared a salt solution containing $48 \mathrm{~g} / \mathrm{L} \mathrm{NaOH}, 230 \mathrm{~g} / \mathrm{L} \mathrm{NaNO}_{3}$, and $21 \mathrm{~g} / \mathrm{L} \mathrm{NaNO}_{2}$. NaTPB, 3PB, 2PB, and $1 \mathrm{~PB}$ were added to $100 \mathrm{ml}$ samples of the salt solution. Table 1 shows the phenylborate concentrations in the solutions and compares them with the target concentrations and the ITP flowsheet. ${ }^{3}$ The solutions were mixed and filtered with a $0.45 \mu$ filter. A $36.50 \mathrm{ml}(44.16 \mathrm{~g})$ sample of each salt solution was mixed with $5.18 \mathrm{~g}$ of cement, $23.33 \mathrm{~g}$ of slag, and $23.33 \mathrm{~g}$ of flyash. The samples were placed in glass kettles which had two ports and were sealed. One port was connected to an air purge. An orbo tube was placed on the other port which discharged into a hood. The orbo tubes were changed periodically and analyzed to determine the amount of benzene released from the saltstone samples. The saltstone prepared with salt solution 1 cured at ambient temperature for 138 days. The saltstone sample prepared with salt solution 2 was placed in a sand bath and heated to $85^{\circ} \mathrm{C}$ for two days. After two days, the heater was turned off and the saltstone cured for another 136 days. 
The $3 \mathrm{~PB}$ and $2 \mathrm{~PB}$ concentrations were within $20 \%$ of the target concentrations. The $1 \mathrm{~PB}$ concentration was less than the detection limit. Since the $1 \mathrm{~PB}$ target concentration was very close to the detection limit, the potential benzene from 1PB is about $2 \%$ of the total potential benzene, and previous testing has shown 1PB decomposition produces very little benzene in saltstone, the low $1 \mathrm{~PB}$ concentration should not be a concern.

The TPB concentration in the samples is less than the target value. The reason for this result is probably the difficulty in dissolving the TPB into salt solution. The low TPB concentration should not be a concern. Previous SRTC testing has shown most of the benzene production in saltstone is from 3PB and 2PB decomposition. ${ }^{5}$ Additionally, other testing has shown KTPB is stable to $200^{\circ} \mathrm{C}$ which is much higher than the maximum temperature expected in Z-area. ${ }^{6}$

Table 1. Composition of Salt Solutions Used to Prepare Saltstone Samples ${ }^{3}$

\begin{tabular}{|c|c|c|c|c|c|}
\hline$\underline{\text { Salt Solution }}$ & $\underline{\mathrm{TPB}}(\mathrm{mg} / \mathrm{L})$ & $\underline{3 \mathrm{~PB}(\mathrm{mg} / \mathrm{L})}$ & 2PB (mg/L) & $\underline{1 \mathrm{~PB}(\mathrm{mg} / \mathrm{L})}$ & $\begin{array}{l}\text { Curing } \\
\text { Temp. }\end{array}$ \\
\hline Simulant \#1 & $<10$ & 318 & 20 & $<10$ & Ambient \\
\hline Simulant \#2 & $<10$ & 318 & 20 & $<10$ & $85^{\circ} \mathrm{C}$ \\
\hline Target & 766 & 364 & 24.2 & 10.8 & N/A \\
\hline Flowsheet $^{4}$ & 383 & 182 & 12.1 & 5.4 & N/A \\
\hline $12 / 96$ test $^{5}$ & 109 & 1689 & 161 & 71 & Ambient \\
\hline
\end{tabular}

Results

Table 2 and Figure 1 show the benzene evolution data (the uncertainty in the measured evolution rates is $\pm 8 \%$ ). The 12/96 test data was interpolated to calculate average benzene release rates over 138 days. The sample which was heated to $85^{\circ} \mathrm{C}$ showed a peak evolution rate of $60 \mu \mathrm{g} / \mathrm{L} \mathrm{hr}(73,400 \mu \mathrm{g} / \mathrm{mole} 3 \mathrm{~PB} \mathrm{hr})$ within the first seven days. After seven days, the evolution rate declined and averaged $16 \mu \mathrm{g} / \mathrm{L} \mathrm{hr}(19,100 \mu \mathrm{g} / \mathrm{mole} 3 \mathrm{~PB} \mathrm{hr})$ over 138 days. That sample released $27 \%$ of the theoretical maximum over the test. The peak release rate in the sample which was heated to $85^{\circ} \mathrm{C}$ was higher than the peak release rates in the samples which cured at ambient temperature. The peak release rate also occurred sooner. The average release rate from the sample which was heated to $85^{\circ} \mathrm{C}$ was within $10 \%$ of the average release rate of the $12 / 96$ test. The average release rate was $50 \%$ higher in the sample which was heated to $85^{\circ} \mathrm{C}$ than the sample in the current test which cured at ambient temperature.

The sample which cured at ambient temperature showed a peak benzene evolution rate of $17 \mu \mathrm{g} / \mathrm{L} \mathrm{hr}(20,800 \mu \mathrm{g} /$ mole 3PB hr) after 70 days which is consistent with previous SRTC testing. The average benzene evolution rate in this test was $10 \mu \mathrm{g} / \mathrm{L} \mathrm{hr}(12,700 \mu \mathrm{g} / \mathrm{mole} 3 \mathrm{~PB} \mathrm{hr})$. The sample released $18 \%$ of the theoretical maximum over 138 days. The peak release rate and average release rate are less than the rates measured in the 12/96 test. The differences could be due to differences in phenylborate concentrations in the saltstone samples or to experimental uncertainty.

Table 2. Composition of Salt Solutions Used to Prepare Saltstone Samples ${ }^{3}$

\begin{tabular}{cccccc} 
Salt Solution & $\begin{array}{c}\text { Time } \\
(\text { days })\end{array}$ & $\begin{array}{c}\text { Peak Release Rate } \\
(\mu \mathrm{g} / \text { mole 3PB hr })\end{array}$ & $\begin{array}{c}\text { Avg. Release Rate } \\
(\mu \mathrm{g} / \text { mole 3PB hr })\end{array}$ & $\begin{array}{c}\text { Yield } \\
(\%)\end{array}$ & $\begin{array}{c}\text { Curing } \\
\text { Temperature }\end{array}$ \\
\hline Simulant \#1 & 138 & 20,800 & 12,700 & 18 & Ambient \\
Simulant \#2 & 138 & 73,400 & 19,100 & 27 & $85^{\circ} \mathrm{C}$
\end{tabular}




$\begin{array}{llllll}12 / 96 \text { test }^{5} & 328 & 53,300 & 15,600 & 31 & \text { Ambient } \\ 12 / 96 \text { test }^{5} & 138 & 53,300 & 17,400 & 25 & \text { Ambient }\end{array}$

The test results show heating the saltstone sample to $85^{\circ} \mathrm{C}$ for two days does not significantly change the amount of benzene released, but causes the benzene release to occur sooner. The peak release rate of the sample which was heated to $85^{\circ} \mathrm{C}$ increased by $37 \%$ over the sample in the $12 / 96$ test.

\section{Conclusions}

The results and conclusions of this test are:

- The saltstone sample which was heated to $85^{\circ} \mathrm{C}$ for two days released benzene at an average rate of $16 \mathrm{ug} / \mathrm{L} \mathrm{hr}$ over 138 days. The maximum release rate $(60 \mathrm{ug} / \mathrm{L} \mathrm{hr})$ occurred during the first seven days. The total benzene release was $27 \%$ of the theoretical maximum.

- The saltstone sample which cured at ambient temperature released benzene at an average rate of $10 \mathrm{ug} / \mathrm{L} \mathrm{hr}$ over 138 days. The maximum release rate $(17 \mathrm{ug} / \mathrm{L} \mathrm{hr})$ occurred after 70 days which is consistent with previous SRTC testing. The total benzene release was $18 \%$ of the theoretical maximum.

- The test shows the total amount of benzene released from saltstone samples during curing does not change much if the sample temperature increases to $85^{\circ} \mathrm{C}$ for a few days, but the increased temperature will cause the benzene to be released sooner and the peak release rate to be higher.

No further saltstone testing is recommended.

\section{References}

1. A. W. Wiggins, "Production of Benzene from TPB and Decomposition Products in Saltstone", HLE-TTR97026, Rev. 0, November 14, 1996.

2. M. R. Poirier, "Benzene TCLP Results from Saltstone Prepared with NaTPB and Its Decomposition Products", WSRC-RP-97-0036, February 4, 1997.

3. Tom White, “HPLC Results”, SRT-ADS-97-0438, September 25, 1997.

4. Glenn Taylor, "More Saltstone Stream Stuff”, e-mail, January 27, 1997.

5. M. R. Poirier, "Impact of NaTPB and Its Decomposition Products on the Saltstone Process", WSRC-RP-97268 May 71997.

6. J. Chiu, “Analytical Report - Cesium Tetraphenyl Boron”, May 12, 1981. 
Approval

Author

M. R. Poirier, WPT

Design Check

M. J. Barnes, WPT

Customer Approval

C. McVay, Saltstone

J. T. Carter, ITP Flow-Sheet Team

Management Approval

W. B. Van Pelt, WPT

W. L. Tamosaitis, WPT 
Figure 1. Effect of Curing Temperature on Saltstone Benzene Evolution

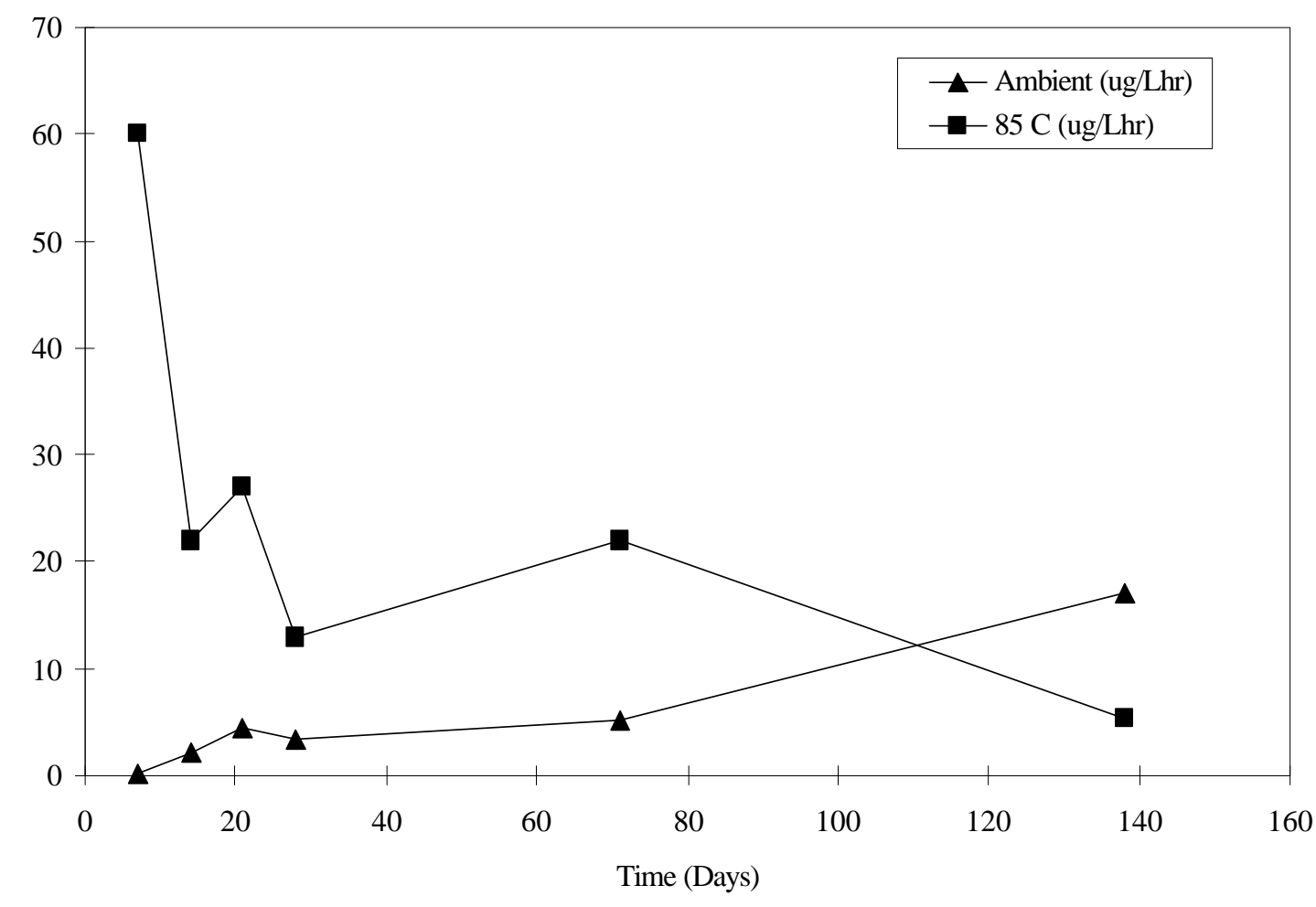

